\title{
Recruitment of Ascophyllum nodosum: wave action as a source of mortality*
}

\author{
Robert L. Vadas, Wesley A. Wright, Steven L. Miller** \\ Department of Botany \& Plant Pathology, University of Maine, Orono, Maine 04469, USA
}

\begin{abstract}
The brown alga Ascophyllum nodosum (L.) Le Jolis is a dominant rocky intertidal organism throughout much of the North Atlantic Ocean, yet its inability lo colonize exposed or denuded shores is well recognized. Our experimental data show that wave action is a major source of mortality to recently settled zygotes. Artificially recruited zygotes consistently exhibited a Type IV survivorshp curve in the presence of moving water. As few as 10 , but olten only 1 relatively low energy wave removed 85 to $99 \%$ of recently settled zygotes. Increasing the setting time for attachment of zygotes (prior to disturbance irom water movement) had a positive effect on survival. However, survival was significantly lower at high densities, and decreased at long (24 h) setting times, probably as a result of bacteria on the surface of zygotes. Spatial refuges provided significant protection from gentle water movement but relatively little protection from waves. These data indicate that zygotes are maladapted for attachment in moving water and suggest that water movement is the primary factor controlling recruitment and distributional pattems of $A$. hodosum. These and earlier observations on the long-term lack of colonization of denuded shores suggest that successful recruitment is highly episodic on all but the most sheltered shores. Because of the widespread dominance of $A$. nodosum, disturbance by waves or currents, and stochastic events may play major roles in structuring intertidal communities in the Northwest Allantic.
\end{abstract}

\section{INTRODUCTION}

Wave action is generally considered an important factor in the distribution and abundance of intertidal organisms. There are, however, few quantitative data on the specific effects of waves on patterns of species abundance. Biological exposure scales describe the direct or indirect effects of waves (Ballantine 1961, Dalby et al. 1978), but they do not characterize what aspects of wave energy are important to the dynamics of a species. Altempts to quantify wave forces are noteworthy (Jones \& Demetropoulos 1968. Harger 1970, Doty 1971), although they all have limitations (Denny 1985a). In general, little attention has been paid to measuring abiotic forces on rocky shores (Palumbi 1984).

Waves affect intertidal communities by damaging individuals and by displacing plants and animals, either individually or in groups (Schwenke 1971, Con-

\footnotetext{
- Maine Agricultural Experiment Station Publication No. 1407

- Present address: NURC-FDU, 40 Estate Castle Coakley, St. Croix, U.S. Virgin Islands 00820
}

neli 1972. Grant 1977, Vadas 1979, Denny et al. 1985). Wave energy also causes indirect mortality to juvenile and adult assemblages through movement of algal fronds, logs, rocks and debris (Connell 1961, Dayton 1971. Velimirov 1983, Sousa 1984). Considerably less is known about the effects of wave forces on juvenile stages of marine organisms. Wave action, however, directly reduces the density of newly recruiled barnacles (Ortega 1981). Few studies have analyzed wave effects on recruiting or juvenile algae. Nonetheless, such data may be essential for understanding the abundance patterns and dynamics of a species and community organization (Sebens \& Lewis 1985).

Along the northern Gulf of Maine the dominant intertidal organism is the brown alga Ascophyllum nodosum (L.) Le Jolis (Keser et al. 1981. Topinka et al. 1981, Vadas \& Wright 1986). Despite its abundance on these and other North Atlantic shores, 2 striking patterns are apparent: a marked decline or absence of plants (especially juveniles) on wave-exposed shores and a general lack of recruitment on all shores (Oltmanns 1889, deVirville 1953, Printz 1956, Boney 1966. Baardseth 1970). Twenty years of observation at Lamoine Maine, USA, revealed no successful coloniza- 
tion by A. nodosum despite its abundance at this and adjacent sites (Vadas \& Wright 1986). This particular population has noticeably declined in cover during the last 5 to $10 \mathrm{yr}$. Several other sites in Maine show similar recruitment patterns, with few exceptions (Keser \& Larson 1984).

Although Littorina littorea (L) grazes on or disturbs sporelings of Ascophyllum nodosum (Sundene 1973, Watson \& Norton 1985, Patterson 1986), cage experiments designed to exclude this herbivore have produced only one natural recruit since 1972 (Vadas unpubl.). Moreover, attempts to recruit A. nodosum artificially by pouring zygotes over numerous caged natural surfaces have also failed to produce significant recruitment (Vadas \& Wright 1986). This apparent enigma, the dominance of $A$. nodosum and the concurrent lack of visible recruitment on these and European shores, raises the question of what controls colonization?

Here we examine recruitment and early survival $(\leq 24 \mathrm{~h})$ of zygotes in artificial and natural wave energy environments as a function of setting or attachment time. densily and surface texture. In particular, we address the following questions: (1) Does wave action affect recruitment and, if so, what controls its effect? (2) Does setting or attachment time affect recruitment? (3) Are refuges important to recruitment and early survivali Our experiments demonstrate that wave action, and water motion in general, is a major source of mortality to zygotes of Ascophyllum nodosum. Longer setting times and refuges enhance survival but only in gentle flowing waters. These results suggest that zygotes of $A$. nodosum are malsidapterl to water movemerl, and that natural recruitment is episodic, except perhaps on very' sheltered shores and among holdfasts in dense stands.

\section{METHODS}

Pottery chips were used as a synthetic substrate for recruitment because of their favorable attachment qualities, water holding potential and ease of removal for sampling (Hanic \& Pringle 1978). The clay consisted of a mixture of Tennessee Ball Clay and Kaolin. Clays containing uron oxides were avoided because they may be toxic. Silica, nephaline, bentonite and whiting were added to the mixture; silica to lower the melting point, nephaline and bentonite as suspension agents, and whiting as a coloring agent. Upon firing the clay turned a flat white providing a reflective rather than a heatabsorbing surface. Clay was rolled out in $1 \mathrm{~cm}$ thick slabs, cut into $5 \mathrm{~cm} \times 5 \mathrm{~cm}$ squares and allowed to dry to a leathery consistency. Holes $(0.5 \mathrm{~cm})$ were drilled through the centers of the squares which were then fired at $983^{\circ} \mathrm{C}$ (Cone 8). The chips had a water-holding capacity of $21 \%$, determined by drying for $48 \mathrm{~h}$, boiling in distilled water for $2 \mathrm{~h}$ to remove air, soaking for $24 \mathrm{~h}$, weighing and drying to a constant weight at $60^{\circ} \mathrm{C}$.

The surfaces of some pottery chips (Expt 4) were modified to simulate natural surfaces and provide refuges for zygotes and germlings. One half of the unfired clay surface was imprinted with a nylon mesh netting while the other half was imprinted with \#50 grade sandpaper. This technique created 4 microhabitats: vertical and horizontal grooves, flat surfaces, and pits. Approximately 32 squares per chip (flat surfaces, $5 \times 4 \mathrm{~mm}$ ) were formed by the mesh. The depth and width of the grooves ranged from 0.1 to $0.2 \mathrm{~mm}$ and from 0.15 to $0.2 \mathrm{~mm}$, respectively. The grooves were designated vertical (parallel to water flow) and horizontal (perpendicular to water flow); survival was analyzed separately in each. The number and size of the squares and characteristics of the grooves varied slightly because of differential stretching of the nylon and differences in tiring and cooling temperatures.

Zygotes were seeded onto pottery chips as follows Gametes of Ascophyllum nodosum are released naturally over a 4 to 6 wh period (April to Junel in Maine. Eggs and sperm were obtained by separately forcing release (by drying) of male and female receptactes in shaded trays. Gamete release occurred in 1 to 2 b on mild sunny days, but took considerably longer under cool cloudy conditions. Gameles were collected by rinsing receptacles in beakers containing cool (10 to $15^{\circ} \mathrm{C}$ ) seawater. To initiate fertilization, gametes of each sex were diluted with seawater, combined to produce a dark turbid broth and stirred for $30 \mathrm{~s}$. In the first experiment 15 min was allowed for fertilization. Subsequently a minimum of $30 \mathrm{~min}$ was employed. Following fertilization the zygote suspension was further diluted and gently poured over chips in shallow pans. The chips were covered by $1 \mathrm{~cm}$ of the suspension and left undisturbed. The pans were shaded and covered with: atumnum foil to prevent warming and enhance germination. After the prescribed setting time, the solution was carefully siphoned from the pans to minimize disturbance. The chips were randomized, gently removed from the pans, subjected to wave or water movement and then placed in moist, covered pans until sampled. Zygotes were regularly misted (fine spray) with cold seawater to prevent desiccation until censusing was complete.

Zygotes in Expts 1, 2, and 3 were counted by first estimating densities of entire chips as light, medium and heavy, and then by random subsampling using eyepiece grids. In Expl 4, zygotes were counted on 18 squares (flats) on light density chips ( $<20$ per flat). On medium density chips (21 to 200 per flat), zygotes were counted on 6 randomly selected flat squares. For high 
density chips (>200 per flat), 6 randomly selected flats were subsampled using an eyepiece grid. The number of zygotes in randomly selected horizontal and vertical grooves was estimated and placed into 7 categories: 0 , $1-25,26-50,51-75,76-100,101-125$ and $>125$ zygotes per groove. Zygotes on the pitted surface were counted in 10 randomly selected pits. Comparisons between and within grooves and pits were difficult because they contained unequal areas and were not easy to quantify. As a result, data for all surfaces were converted to percent survival of control chips. Controls in all experiments consisted of chips handled identically to experimental chips except for the specific treatment.

Expt 1 was designed to simulate the recent settlement of zygotes in the field and to determine the impact of natural (low energy) waves on survival. To simulate the short period available for natural gamete release and zygote attachment during a flooding tide. zygotes were seeded onto chips and allowed to set undisturbed for only $15 \mathrm{~min}$. Chips were randomized and exposed to waves either individually (Trial 1 ) or as a group by mounting them on plywood strips (Trial 2). The individual chips or strips were hand-held, appressed to the rock surface, and subjected to 6 (Trial 2) or 8 (Trial 1) different wave treatments at Pemaquid Pt (sec) Fig. 1). Control chips were maintained in air, but misted with seawater, for the duration of the longest wave series (16) in each trial. This provided a conservalive estimate of control levels for chips exposed to fewer waves. Control densities averaged $1228 \pm 260$ and $270 \pm 41$ zygotes $\mathrm{cm}^{-2}$ (mean $\pm \mathrm{SD}$ ), respectively, for Trials $1(n=3)$ and $2(n=5)$.

Expt 2 was designed to simulate the effects of low energy waves on survival. The wavemaker was an 101 asymmetrical open-topped plexiglas box (one side with an obtuse anglel. The box was mounted on cylindrical pivots over a plexigias tank connected to flowing seawater. As the box filled it became unbalanced and spilled the water, creating a wave 2 to $5 \mathrm{~cm}$ high.

Zygotes were seeded onto pottery chips and allowed to attach for 9 different time intervals. After seeding, but beforc testing, experimental and control chips were maintained in seawater in large shallow pans. At the end of each selting period 12 chips ( 3 per treatment) were carefully removed, placed on a rack $35 \mathrm{~cm}$ from the wave machine and exposed to a series of $1,2,4$ or 8 waves. Control densities for the $24 \mathrm{~h}$ treatments averaged $1865 \pm 43$ zygotes $\mathrm{cm}^{-2}$ (mean $\pm \mathrm{SD}, \mathrm{n}=3$ ).

Expt 3 was designed to test the influence of low, medium and high zygate densities and different setting times on survivorship. This experiment was conducted in gently moving water to minimize the dominating effect of water movement on other variables. This series was also used to determine if artifacts werc mnolved in the low survival at long setting times in pilot studies and Expt 2. Zygotes were subjected to 9 setting intervals in 2 series: (a) 0.5, 1, 2, 3 and $4 \mathrm{~h}$ and (b) $6,12,16$, and $24 \mathrm{~h}$. Following settlement, 6 replicated chips were placed in a reciprocal shaker bath at $10^{\circ} \mathrm{C}$ for 1 min at 68 oscillations min $^{-1}$. This produced a flow velocity of $6108 \mathrm{~cm} \mathrm{~s}^{-1}$ (determined with a heated-bead thermister flowmeter; Vogel 1981), which resulted in a $1.5 \mathrm{~cm}$ overwash of each chip. Although this experiment simulated intertidal water movements. acceleration forces off the sides of the tank could have increased dislodgment of zygotes. Controls for Series (a) and (b) were based on the 4 and $24 \mathrm{~h}$ setting times, respectively, and were maintained in calm water at $10^{\circ} \mathrm{C}$. Controls for the low, medium and high density treatments averaged, respectively, (mean $\pm \mathrm{SD}$ ) $53 \pm 9,448 \pm 31$ and $5378 \pm 1434$ zygotes $\mathrm{cm}^{-2}$ for Series (a) and $16 \pm 2,174 \pm 41$ and $3006 \pm 537$ zygotes $\mathrm{cm}^{-2}$ for Series (b). To test for differences between density treatments, analysis of variance (ANOVA), linear regression and analysis of covariance (ANCOVAR) were employed (Sokal \& Rohlf 1981). Log $(n+1)$ transformations were used to equalize the variance.

To test for the possibility that attachment of zygotes was influenced by environmental conditions (long setting times, high zygote densities and bacterial growth), bacteria adhering to zygotes were removed at $1,4,7$, 11,15 and $24 \mathrm{~h}$ with a sonicator (Branson 2200). Five zygotes per setting time wore individually isolated and sonicated for $30 \mathrm{~s}$ in sterile seawater. The suspension was plated on $0.1 \%$ glucose and tryptone agar, incubated at $10^{\circ} \mathrm{C}$ for $24 \mathrm{~h}$, and counted.

Expt 4 was designed to test the influence of refuges, setting times and natural water movement on zygote survival at contrasting exposures: Pemaquid Point, an exposed site, and Montsweag Bay, a sheltered estuarine site (Fig.1). Zygotes from plants collected near Penaquid $\mathrm{Pt}$ were allowed to set on chips mounted on boards. A multifactorial design consisting of 3 wave treatments $(1,10$ and 100 waves), $4 \mathrm{mi}$ crohabitat types (llat, pitted and vertically and horizontally grooved surfaces) and 3 setting times (1,2 and $4 \mathrm{~h}$ ) was utilized and replicated 10 times per treatment. Because of the absence of waves at Montsweag Bay, zygotes were immersed at the edge of the water during a llooding tide for $5 \mathrm{~s}, 2$ and $20 \mathrm{~min}$. These periods were equivalent to the times required to complete the 3 wave treatments at Pemaquid Pt. Densities of control chips (100 wave treatment) at Pemaquid Pt averaged $1577 \pm 838,1715 \pm 592$ and $860 \pm 634$ (mean $\pm \mathrm{SD}$. $\mathrm{n}=10) \mathrm{cm}^{-2}$ for 1,2 and 4 h setting times, respectively. Control densities at Montsweag Bay (20 min treatment) averaged $1814 \pm 1190,2062 \pm 860$ and $3072 \pm 1063$ $(\mathrm{n}=10)$ for the 1,2 and $4 \mathrm{~h}$ treatments. The data were 


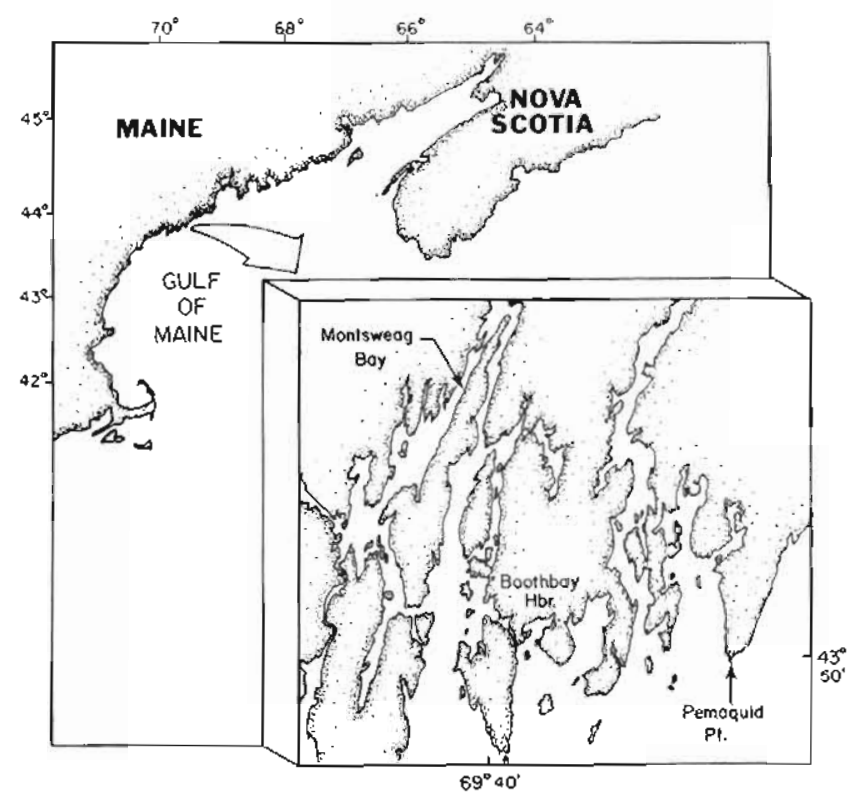

Fig. 1. Location of exposed (Pemaquid Pt) and sheltered (Montsweag Bay) experimental sites

converted to percent (as noted above), (ransformed with an angular transfomation, and analyzed with a 3-way ANOVA.

\section{RESULTS}

\section{Expt 1}

Zygotes set for $15 \mathrm{~min}$ on smooth pottery chips and exposed to natural wave action $(20$ to $50 \mathrm{~cm}$ high waves) showed a classical Type IV survivorship curve (Fig. 2). Approximately $90 \%$ of the zygotes were removed by the initial wave in both trials.

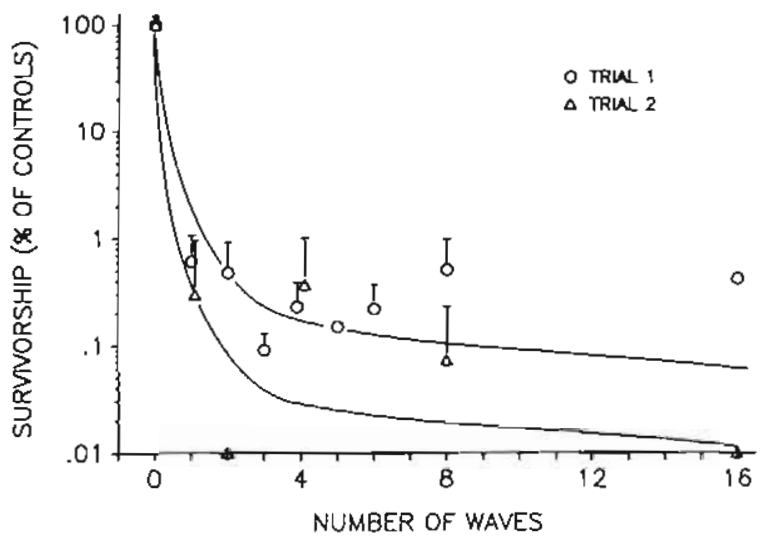

Fig. 2. Ascophyllum nodosum. Relative survivorship of zygotes (mean \pm SD) recruited for 15 min and exposed to natural waves at Penaquid Pt. The absence of error bars indicates that the standard deviation was within the symbol. ' 0 ' waves denotes controls
Expt 2

Survival of zygotes, allowed to set over a wide range of times and exposed 10 artifically generated waves, exhibited a Type IV survivorship curve except at the 3 and $6 \mathrm{~h}$ setting times. At the shortest ( $5 \mathrm{~min}$ to $1 \mathrm{~h}$ ) and longest ( 12 to $24 \mathrm{~h}$ ) selling times, survival was reduced. Survival appeared to be enhanced at intermediate setling limes and after 1 wave was almost an order of magnitude higher than the other treatments (Fig. 3).

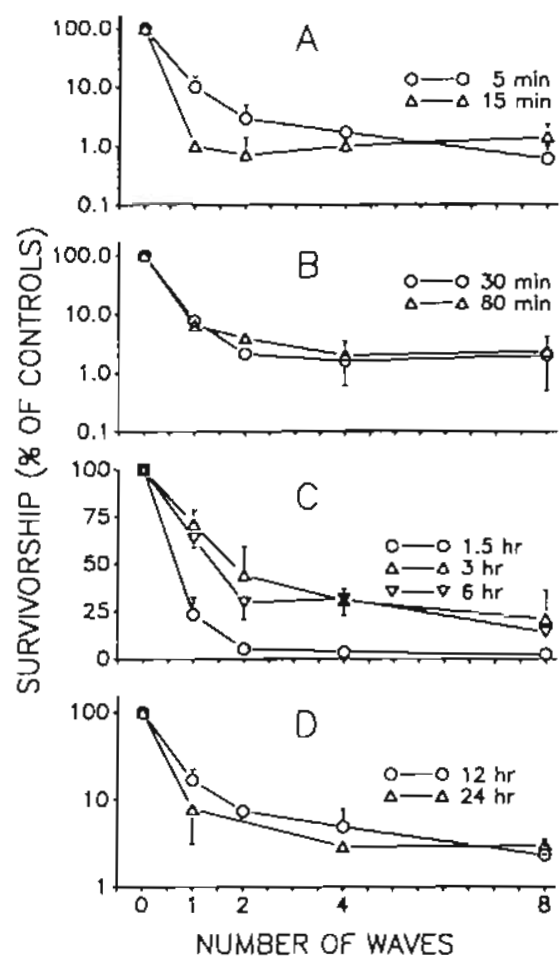

Fig. 3. Ascophyllum nodosum. Influence of setting time (A and $B=$ short, $C=$ intermediate, $D=$ long) and waves on relative survivorship of zygotes (mean $\pm \mathrm{SD}$ ) in a wave tank. '0' waves denotes controls. Note: the y-axes are not the same for each figure

Expt 3

Survival of zygotes exposed to low flow velocities in a shaker bath was positively correlated with selling time up to 3 or 4 h (Fig. 4). Survival ol zygotes at 3 to 4 h was equivalent to control treatments absence of water movement). The 3 density curves in Series (a) fit a cubic polynomial regression line with ecpual slopes but unequal intercepts. At high density survival of zygotes was significantly lower than at medium and light densities $(p<0.05)$. Survival at low and medium densities for longer selting times was equivalent to 
Fig. 4. Ascophylum nodosum. Influence of density and setting times on survivorship of zygates. Trials conducted under low water movement and in 2 series: (a) 0.5 to $4 \mathrm{~h}$, and (b) 6 to $24 \mathrm{~h}$. Data were $\log (n+1)$ transformed; values shown are means $\pm 95 \% \mathrm{CI}$. L, M. H denote controls for low, medium and high density after $4 \mathrm{~h}$ (Serics a) and $24 \mathrm{~h}$ (Series b)

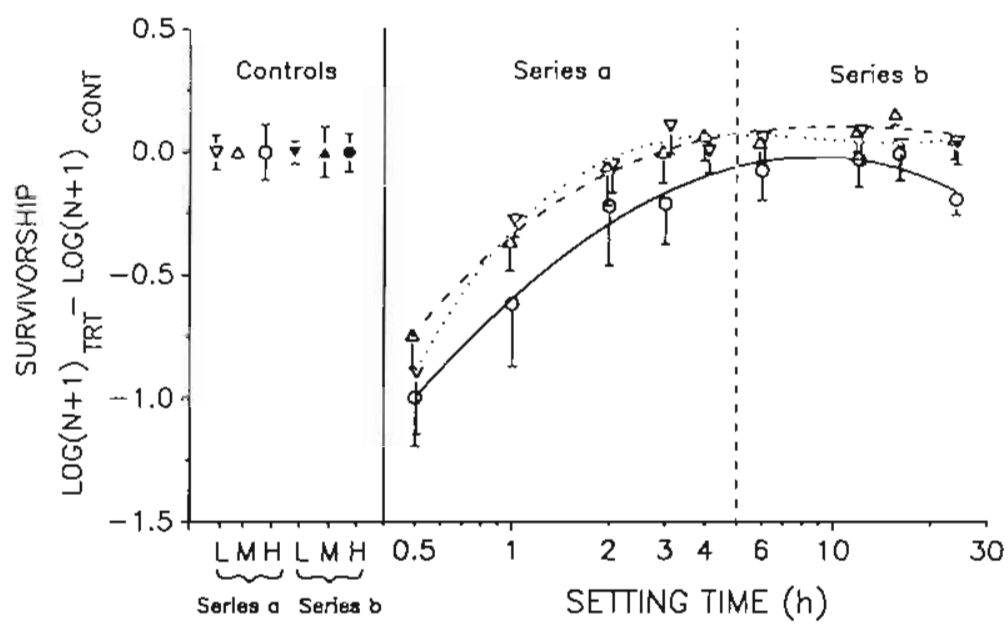

controls through 24 h (Fig. 4). However, at high density there was a significant decrease in survival at the longest setting time $(p<0.05)$.

Bacteria isolated from zygotes after $15 \mathrm{~h}$ (setting time) in medium and high densily treatments ( $n=5$ plates, 6 counts plate ${ }^{-1}$ ) produced significantly $(\mathrm{p}<0.05)$ more colonies $(60.1 \pm 29.4$ and $44.4 \pm 29.1$, mean $\pm \mathrm{SD}$. zygote $^{-i}$, respectively) than similar isolates from low density cultures $(13.9 \pm 5.2$, mean \pm SD, colonies zygote ${ }^{-1}$ ). Bacteria isolated from shorter treatments $(<15 \mathrm{~h}$ ) grew at similar rates regardless of zygote density.

\section{Expt 4}

Zygotes set for 1,2 or $4 \mathrm{~h}$ on flats or refuges, and exposed to a series of natural waves (20 to $40 \mathrm{~cm}$ high) at Pemaquid Pt exhibited Type IV survivorship curves. Regardless of treatment, most recruits were lost with the first wave. Because there were no significant differences $(p<0.05$ ) between pils and grooves (one exception; Table 2), these calegories wero rumbined for clarity (Fig. 5). Survival was always lowest on the flats and ranged from 7 to $16 \%$ after 1 wave and from 1 to $5 \%$ after 10 waves. Less than $0.2 \%$ survived after 100 waves. Survival in pits and grooves was significantly higher than on flat surfaces for 1 and 10 waves. However, cohorts in these refuges also approached extinction after 100 waves.

Survival of zygotes exposed to a gently flooding tide in Montsweag Bay was substantially higher than at Pemaquid Pt. Survival was again lowest on the flats, ranging from 65 to $100 \%$ after $5 \mathrm{~s}$ and from 59 to $82 \%$ and 27 to $45 \%$ after 2 and 20 min, respectively (Fig. 6). Conversely, mortality was almast non-existent in the pits and grooves after $5 \mathrm{~s}$ and $2 \mathrm{~min}$. After $20 \mathrm{~min}$, survival in refuges ranged from 80 to $92 \%$ in the 1 and $2 \mathrm{~h}$ treatments and was $49 \%$ in the $4 \mathrm{~h}$ treatment.

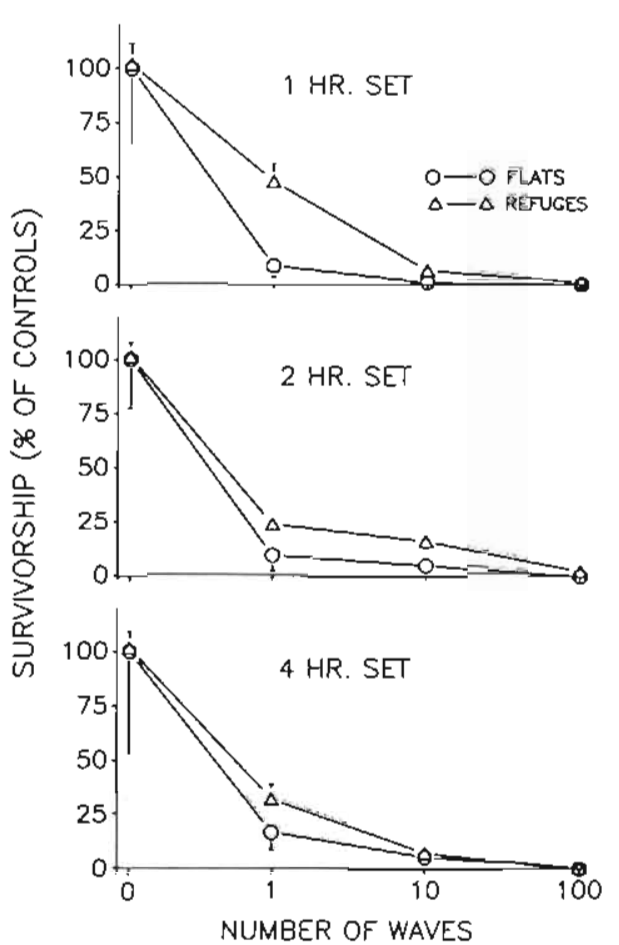

Fig. 5. Ascophyllum nodosum. Effects of successive waves, refuges and setting times on relative survivorship of zygotes (mean $\pm 95 \% \mathrm{Cl}$ ) at Pemaquid Pt. ' 0 ' waves denotes controls. Wave amplitudes ranged from 20 to $40 \mathrm{~cm}$ during the experiment

Al Pemaquid Pt all main effects, except setting time, and all interactions were significant, whereas at Montsweag Bay all main effects and the selling time vs immersion time interaction were significant (3-way ANOVA, $p<0.05$ ). Because of the occurrence of sigrificant interaction terms and the dominating influence of waves on survival, the influence of surface texture or setting time upon survivorship were examined al each level of wave (or immersion) exposure (Tables 1 and 2). 


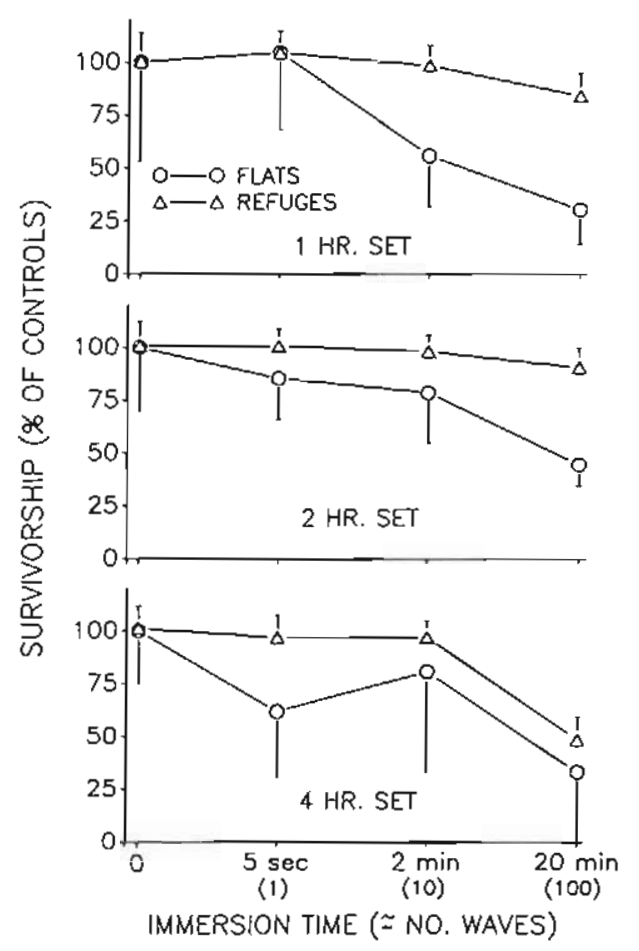

Fig.6. Ascophylum nodosum. Effects of immersion times $l=$ No. waves at Pemaquid $\mathrm{Pt}$ ), refuges and setting times on relative survivorship of zygotes (mean $\pm 95 \%$ CI) at Montsweag Bay. ' 0 ' waves denotes controls. Water movement was limited to that caused by a gently flooding tide

Significant differences within each level of wave exposure were determined by the Ryan-Elinot-GabrielWelsch multiple $F$ test (REGWF) (SAS Institute Inc.
1982). Survival on flat surfaces was significantly different from textured surfaces at each wave treatment and at both sites except for 100 waves at Pemaquid Pt. Significant differences among setting times occurred at Pemaquid Pt but varied in an unordered manner in all wave treatments. This was caused by variation in wave forces, especially in single wave treatments. Such variation was averaged out in multiple wave trials. No significant differences were observed among setting times at the shorter immersion periods in Montsweag Bay. However, after immersion for $20 \mathrm{~min}$ zygotes established for 1 and $2 \mathrm{~h}$ exhibited better survival $(\mathrm{p}<0.05)$ than those set for $4 \mathrm{~h}$.

\section{DISCUSSION}

Our results indicate that water motion is a major source of mortality for zygotes of Ascophyllum nodosum. Laboratory and field experiments, under relatively benign wave conditions, show that water movement reduces recruitment on protected and exposed shores. Irrespective of setting time and whether or not refuges are provided, $851099 \%$ of the zygotes are dislodged by the first 10 waves with most mortality occurring after a single wave. The severity of this disturbance is further accentuated by the virtual loss of entire cohorts within $20 \mathrm{~min}$. Moreover, these estimates of mortality are probably conservative because under natural tidal and water movements the long undisturbed periods required for initial attachment are uncommon. Gametes are usually released at

Table 1. Ascophyllum nodosum. Influence of surface texture on survivorship of zygotes at different exposures.

\begin{tabular}{|c|c|c|}
\hline Surfaces & $\begin{array}{l}\text { Pemaquid Point (Exposed) } \\
\text { Mean \% survivorship }\end{array}$ & $\begin{array}{l}\text { Montsweag Bay (Sheltered) } \\
\text { Mean \% survivorship" }\end{array}$ \\
\hline & 1 wave & $5 \mathrm{~s}$ \\
\hline Horizontal grooves & $31.3 \mathrm{a}$ & $95.2 \mathrm{a}$ \\
\hline Vertical grooves & $31.4 \mathrm{a}$ & 95.30 \\
\hline Pits & $38.9 \bar{a}$ & $96.5 \mathrm{a}$ \\
\hline \multirow[t]{2}{*}{ Flats } & $9.9 \mathrm{~b}$ & $82.4 b$ \\
\hline & 10 waves & $2 \min$ \\
\hline Horizontal grooves & $10.3 \mathrm{a}$ & $96.9 \mathrm{a}$ \\
\hline Vertucal grooves & $10.0 a$ & $96.0 \mathrm{a}$ \\
\hline Pits & $5.4 \mathrm{~b}$ & $92.0 \mathrm{a}$ \\
\hline \multirow[t]{2}{*}{ Flats } & $2.9 \mathrm{C}$ & $70.6 b$ \\
\hline & 100 waves & 20 min \\
\hline Horizontal grooves & 0.4 & $83.7 \mathrm{a}$ \\
\hline Vertical grooves & 0.4 & $78.4 \mathrm{a}$ \\
\hline Pits & $0.5^{\mathrm{ns}}$ & $67.5 \mathrm{a}$ \\
\hline Flats & 0.1 & $33.1 b$ \\
\hline
\end{tabular}


Table 2. Ascophyllum nodosum. Influence of setting time on survivorship of zygotes at different exposures

\begin{tabular}{|c|c|c|}
\hline Selting lime & $\begin{array}{l}\text { Penaquid Point (Exposed) } \\
\text { Mean } \% \text { survivorship }\end{array}$ & $\begin{array}{c}\text { Montsweag Bay (Sheltered) } \\
\text { Mean " } " \text { survivorship" }\end{array}$ \\
\hline & 1 wave & $5 s$ \\
\hline $1 \mathrm{~h}$ & $35.9 \mathrm{a}$ & 96.1 \\
\hline $2 \mathrm{~h}$ & $19.5 c$ & $94.3 \mathrm{~ns}$ \\
\hline \multirow[t]{2}{*}{$4 \mathrm{~h}$} & $26.5 b$ & 87.9 \\
\hline & 10 waves & $2 \mathrm{~min}$ \\
\hline $1 \mathrm{~h}$ & $3.7 \mathrm{C}$ & 88.9 \\
\hline $2 h$ & $12.0 \mathrm{a}$ & $93.4 \mathrm{~ns}$ \\
\hline \multirow[t]{2}{*}{$4 \mathrm{~h}$} & $5.7 b$ & 896 \\
\hline & 100 waves & $20 \mathrm{~min}$ \\
\hline $1 \mathrm{~h}$ & $0.1 \mathrm{~b}$ & $73.5 \mathrm{a}$ \\
\hline $2 \mathrm{~h}$ & $0.7 \mathrm{a}$ & $79.8 \mathrm{a}$ \\
\hline $4 h$ & $0.2 \mathrm{~b}$ & $44.5 b$ \\
\hline
\end{tabular}

ebb tide, especially on warm sunny days and are washed free of the receptacles with the incoming tide (Bacon \& Vadas unpubl.). Thus, little (motionless) time is available for in situ fertilization and attachment. Hence Expt 1, which shows an extreme Type IV survivorship curve, most closely simulates the conditions found in nature on moderate to wave-exposed shores. These data also indicate that the movement of a flooding tide, excepl perhaps on highly sheltered shores, e.g. Montsweag Bay, makes attachment of newly formed zygotes extremely difficult.

Survival patterns of zygotes were similar in all experiments despite the wide range of wave treatments and setting times used. The shortest selting times fup to $1.5 \mathrm{~h}$ ) were consistently least conducive to survival. The reduced survival of zygotes in the 4 h treatment at Montsweag Bay (Expt 4) and the enhanced survival at intermediate selting times (Expt 2) should be noted. 'lhe $4 \mathrm{~h}$ treatment was run $16 \mathrm{~d}$ after the 1 and $2 \mathrm{~h}$ treatments, and near the end of the natural release period for Ascophyllum nodosum in Maine (zygotes formed from late season gametes appear to be dislodged morc easily; Vadas unpubl.). Preliminary studies and Expt 2 indicated that zygotes recruited for the shortest and longest intervals had the highest mortality: intermediate times (2 to 6 h) seemingly provided best survival. However earlier studies indicated that survival should increase with setting time. Chartrers et al. (1972) showed that carpospores of red ilycir: attached for $19 \mathrm{~h}$ were less easily dislodged that those recruited for 7 to $9 \mathrm{~h}$. Similarly, adhesion of germlings of Sargassum mutucum was enhanced with time (Norton 1983).

Expt 3 clearly demonstrated that attachment or survi- val was positively correlated with setting time. However, this relationship was confounded by high zygote densities, especially at longer setting times which we infer enhanced bacterial growth. Thus it is possible that bacteria were responsible for the reduced survival at long setting times in Expl 2.

The inabiluty of zygotes of Ascophyllum nodosum to adhere quickly and firmly to solid substrata is surprising. Most algae produce mucilage for attachment (Fletcher 1976), but strategies in fucoict algae vary considerably. Zygotes and germlings of Sargassum mulicum are sticky, sink quickly and attach rapidly (Deysher \& Norton 1982). Several fucoids have delayed rhizoidal development and have specialized attachment mechanisms, e.g. mesochiton in Pelvetia and special cell walls in zygotes of Bifurcaria and Himanthalia (Hardy \& Moss 1979. Moss 1981). Zygotes of A. nodosum and Fucus spp. apparently lack stickiness but secrete mucilage through the wall (Moss 1981). Moss (1975) showed that fertilized eggs of A. nodosum produce a mucilage pad immediately after settlement which attaches the zygote to the surface. Subsequently a primary rhizoid is produced which secures the germling to the substratum. Under culture conditions rhizoids form within $24 \mathrm{~h}$ (Patterson 1986) and are enhanced in darkness (Sheader \& Moss 1975). The question of why zygotes of A. nodosum do not attach firmly romains unanswered.

Although 2 types of spatial refuges (pits and grooves) were utilized in our studies, neither was effective in moving water. Microhabitat heterogeneity is often considerud critical to the survival of intertidal organisms (Bergeron \& Bourget 1986). Some species setilc in refuges, and gain a foothold on exposed shores, escape 
predation, or reduce desiccation and other stresses (Dayton 1971). Refuges for fucoid algae generally have been considered escape mechanisms from herbivorous gastropods (Lubchenco 1978, 1983, Schonbeck \& Norton 1980, Vadas ( 1 al. 1982) which are thought to play a significant role in mortality of juvenile fucoids (Sundene 1973, Vadas et al. 1977, Keser et al. 1981, Lubchenco 1980, 1986). However, refuges may also minimize other disturbances to fucoids. In ice-scoured regions of the North Atlantic Ascophyllum nodosum is restncted to crevices and ice-free boulder fields ( $R$. Wilce pers. comm.). In addition, desiccation, light intensity and wave shock pressures (Carstens 1968, Denny 1985b) are reduced in crevices and microhabitats. Survival of germlings of Sargassum muticum, for example, is higher in the lee of roughened surfaces (Norton 1983). Our experiments suggest that refuges enhance survivorship of A. nodosum in low and moderate energy environments by ameliorating disturbance from water movement. This hypothesis is supported by long-term (1 to $2 \mathrm{yr}\}$ survival of germlings in refuges beneath dense canopies on moderately exposed shores (Vadas, Miller \& Wright unpubl.).

The inability of a photosynthetic benthic organism to attach readily to natural surfaces cannot be reconciled easily given the dynamic nature of intertidal environments. Life in the Litoral zone entails coping with water motion, presumably through evolution. However, Ascophyllum nodosum appears to be maladapted to moving water, both in its juvenile slage, as shown here, and possibly in its adult form where high breakage of shoots occurs regularly on exposed and other shores (Vadas 1972, Vadas et al. 1976, 1978). Interestingly, McEachreon \& Thomas (1987) showed that breaking stress in A. nodosum was positively correlated with wave exposure, which suggests that adults are physiologically or genetically adapted to different degrees of wave exposure. It may be unreasonable, however, to expect all life history stages of intertidal organisms to have adapted to water movement. Sea anenomes on exposed shores, for example, avoid mainstream velocities (Koehl 1977) and repopulate rocky shores through asexual means (Sebens 1982), thus eliminating the need' for specific adaptations by the zygote for dealing with high wave forces.

With Ascophyllum nodosum the inability to recruit readily may be compensated by iteroparity and an enormous annual investment in reproduction. $A$. nodosum is a perennial (Baardseth 1970) and, before releasing gametes in the spring invests ca 40 to $50 \%$ of its biomass in reproductive structures (Josselyn \& Mathieson 1978, Vadas unpubl.). Nonetheless, successful recruitment on exposed and moderately exposed shores probably involves a rare combination of mechanisms or stochastic events. Our experiments and long- term observations suggest that large new patches are unlikely to develop, except from synchronously recruiterd cohorts under calm sea conditions lasting for several duys. Although modification of wave energy by adult fucoid stands is also possible, similar to kelp beds (Jackson \& Winant 1983, Tegner 1986), tidally induced water movements probably eliminate all but a trickle of zygotes from recruiting into the understory (Lubchenco 1986, P. Aberg pers. comm., Vadas unpubl.J. Episodic recruitment, which is well recognized in many organisms (White 1985) including marine invertebrates (Coe 1956, Vahl 1982, Sebens \& Lewis 1985, Tegner 1986) and recently algae (Reed et al. 1988), could account for the presence of A. nodosum on moderate and exposed shores. Its presence and repopulation on highly protected shores may be more straightforward (Keser \& Larson 1984) although specific mechanisms are lacking.

The ability of Ascophyllum nodosum to persist as monocultures on many shores probably results from its perennial habit and the presence of a dense understory of suppressed shoots. Cousens (1986) and Vadas \& Wnght (1986) have argued that the presence of small relatively unbranched shoots or plants ('juveniles') is the result of competition for light in dense stands rather than persistent recruitment. These suppressed shoots function as 'meristem banks' (Cousens 1985, Vadas \& Wright 1986 ) and are thought to re-establish the bed following disturbance to the canopy. Once established these dense stands or patches of $A$. nodosum appear to occupy space for decades, and thus pre-empt space (Lewis 1976) or oulcompete other fucoids for space through growth and longevity (Schonbeck \& Norton 1980, Keser \& Larson 1984, Cousens 1985, Vadas \& Wright 1986).

The absence of Ascophyllum nodosum from exposed shores has long been recognized but not explained (Lewis 1964). Lewis (1968) suggested that dispersal may be a problem and noted that sporelings were absent in exposed situations. Our inability to recruit zygotes poured over natural surfaces (Vadas \& Wright 1986) indicates that dispersal per se is not the cause of distribution patterns. Similarly, the absence of $A$. nodosum from curreni swept areas (Lewis 1968, Mathieson et al. 1977, Hardwick-Witman \& Mathieson 1983) is probably related to attachment rather than dispersal

This stucly provides additional support for the potential importance of recruitment in structuring benthic assemblages (Underwood \& Denley 1984, Ganes \& Roughgarden 1985). Our data indicate that wave action is an important factor controlling the distribution and abundance of juvenile stages of a dominant species. Although abrotic factors have been neglected in recent decades, they are as important as biotic interactions in determining patterns of abundance (Lewis 1980). Denny et al. 1985, Sebens \& Lewis 1985, Underwood 1986). Since Ascophyllum nodosum is the dominant life 
form on many North Atlantic shores, factors affecting its distribution and abundance may have important ramifications for the structure and organization of rocky intertidal communities.

Acknowledgements. We thank Linda Bacon, Chris Bolis and Patricia Patterson for field assistance, Drs Roger Cousens and Ian Davison for review of earlier dratts and Jean Ketch for typing the ms. We appreciate the constructive criticism of John Pearse and an anonymous reviewer. We acknowledge the support of the Maine Agricultural Experiment Station, the NOAA, National Sea Grant Program to the University of Maine (NA-80-AA-D-00034) and a faculty equipment grant from the University of Maine. R. L. V. acknowledges the Department of Marine Zoology, University of Oslo, The Norwegian Institute of Water Resources (NIVA) and the Norwegian government (NTNF) for providing space and support to write.

\section{LITERATURE CITED}

Baardseth. E. (1970) Synopsis of biological data on knobbed wrack Ascophyllum nodosum (Linnaeus) Le Jolis. FAO Fish. Synopsis, No. 38, Rev. 1

Ballantine, W. J. (1961). A biologically-defined exposure scale for the comparative description of rocky shores. Fld Stud. 1: $1-19$

Bergeron, P., Bourget, E. (1986). Shore topography and spatial partitioning of crevice refuges by sessile epibenthos in an ice disturbed environment. Mar. Ecol. Prog. Ser. 28: $129-145$

Boney, A. D. (1966). A biology of marine algae. Hutchinson Educational Ltd, London

Carstens, T. (1968). Wave forces on boundries and submerged bodies. Sarsia 34: 37-60

Charters, A. C., Neushul, M., Coon, D. A. (1972). Effects of water motion on algal spore altachment. Proc. Inl. Seaweed Symp. 7: 243-247

Coe, W. R. (1956). Fluctuations in populations of littoral marine invertebrates. J. mar. Res. 16: 212-232

Connell, J. H. (1961). Effects of competition, predation by Thas lapillus, and other factors on natural populations of the barnacle Balanus balanoides. Ecol. Monogr. 31: 61-104

Connell, J. H. (1972). Community interactions on marine rocky intertidal shores. Ann. Rev. Ecol. Syst. 3: 169-192

Cousens, R. (1985). Frond size distributions and the effects of the algal canopy on the behaviour of Ascophyllum nodosum (L.) Le Jolss. J. exp. mar. Biol. Ecol. 92: 231-249

Cousens, R. (1986). Quantitative reproduction and reproductive eftort by stands of the brown alga Ascophyllum nodosum (L.) Le Jolis in southeastern Canada. Estuar. coast. Shelf Sci. 22: 495-507

Dalby, D. H., Cowell, E. B., Syratt, W. J., Crothers, J. H. (1978). An exposure scale for marine shores in western Norway. J. mar. biol. Ass. U. K. 58: 975-996

Dayton, P. K. (1971). Competition, disturbance, and community organization: the provision and subsequent utilization of space in a rocky intertidal community. Ecol. Monogr. 41. 351-389

Denny, M. W. (1985a). Water motion. In: Littler, M. M. Littler, D. S. (eds.) Handbook of phycological methods IV: ecological field methods: macroalgae. Cambridge University Press, New York, p. 7-32

Denny, M. W. (1985b). Wave forces on intertidal organisms: a case study. Limnol. Oceanogr. 30: 1171-1187
Denny, M. W., Daniel, T. L., Koehl, M. A. R. (1985). Mechanical limits to size in wave-swept organisms. Ecol. Monogr. 55: $69-102$

deVirville, D. (1953). Dépeuplement de la flore marine sur les cotes occidentales du Cotentin. Proc. Int. Seaweed Symp. 1: $26-28$

Deysher, L., Norton, T. A. (1982). Dispersal and colonization in Sargassum muticum (Yendol Fensholt, J. exp. mar. Biol. Ecol. 56: 179-195

Doty, M. S. (1971). Measurement of water movement in reference to benthic algal growth. Botanica mar. 14: 32-35

Fletcher, R. L. (1976). Post-germination attachment mechanisms in marine fouling algae. In: Sharpley, J. M., Kaplan, A. M. (eds.) Proc. Third Int. Symp. on Biodegradation. Applied Science Ltd., London, p. 443-464

Gaines, S., Roughgarden, J. (1985). Larval settlement rate: a leading determinant of structure in an ecological community of the marine intertidal zone. Prac. natl Acad. Sci. U.S.A. 82: $3707-3711$

Grant, W. S. (1977). High intertidal community organization on a rocky headland in Maine, USA Mar. Biol. 44: 15-25

Hanic, L. A., Pringle, J. D. (1978). Pottery, a substrate for algal culture, Br. Phycol. J. 13: 25-33

Hardwick-Witman, M. N., Mathieson, A. C. (1983). Intertidal macroalgae and macroinvertebrates: seasonal and spatial abundance patterns along an estuarine gradient. Estuar. coast. Shelf Sci. 16: 113-129

Hardy, F. G., Moss. B. L. (1979). Attachment and development of the aygotes of Pelvetia canaliculata (L.) Done. et Thur. (Pháeophyceae, Fucales). Phycologia 18: 203-212

Harger, J. R. E. (1970). The effect of wave impact on some aspects of the biology of sea mussels. Veliger 12:401-4i4

Jackson, G. A., Winant, C. D. (1983). Effect of a kelp forest on coastal currents. Cont. Shelf Res. 2: 75-80

Jones, W. E., Demetropoulos, A. (1968). Exposure to wave action: measurements of an important ecological parameter on rocky shores on Anglesey. J. exp. mar. Biol. Ecoi. 2: 46-63

Josselyn, M. N., Mathieson, A. C. (1978). Contribution of receptacles from the fucoid Ascophyllum nodosum to the detrital pool of a north temperate estuary. Estuaries 1: $258-261$

Keser, M., Larson, B. R. (1984). Colonization and growth of Ascophyllum nodosum (Phaeophyta) in Maine. J. Phycol. 20: $83-87$

Keser, M., Vadas, R. L., Larson, B. R. (1981). Regrowth of Ascophyllum nodosum and Fucus vesiculosus under various harvesting regimes in Maine, USA. Botanica mar. 24: 2938

Koehl, M. A. R. (1977). Effects of sea anemones on the flow forces they encounter. J. exp. Biol. 69: 87-105

Lewis, J. R. (1964). The ecology of rocky shores. English Universities Press, London

Lewis, J. R. (1968). Water movements and their role in racky shore ecology. Sarsia 34: 13-36

Lewis, J. R. (1976). The role of physical and biological factors in the distribution and stability of rocky shore communities. In: Keegan, B. F, Deidigh, P. O., Boaden, P. J. (eds.) Biology of benthic organisms. Pergamon Press, New York, p. 417-424

Lewis, J. R. (1980). Objectives in littoral ecology - a personal viewpoint. In: Price, J. J., Irvine, D. E. G., Farnham, W. F. leds.) The shore environment. Vol. 1. Academic Press, New York, p. 1-18

Lubchenco, J. (1978). Plant species diversity in a marine intertidal community: importance of herbivore food preference and algal competitve abilities. Am. Nat. 112: 23-39 
Lubchenco. J, (1980). Algal zonation in the New England rocky intertidal conımunity: an experımental analysis. Ecology $61: 333-344$

Lubchenco. J, (1983). Littorina and Fucus; effects of herbivores, substratum heterogeneity, and plant escapes during succession. Ecology 64: 1116-1123

Lubchenco. J. (1986). Relative importance of competition and predation: early colonization by seaweeds in New England. In: Diamond, J., Case, T. J. (eds.) Community ecology. Harper and Row, New York, p. 537-555

Mathieson, A. C., Tveter, E., Daly, M., Howard, J. (1977) Marine algal ecology un a New Hampshire tidal rapid Botanica mạr. 20: 277-290

McEachreon, J. C. T., Thomas, M. L. H. (1987). Attachment strength of Ascophylum nodosum (L.) Le Jolis and exposure to wave action. Botanica mar. 30:217-222

Moss, B. (1975). Attachment of zygotes and germlings of Ascophyllum nodosum (L.) Le Jol. (Phaeophyceae, Fucales). Phycologia 14: 75-80

Moss, B, (1981). Attaching mechanisms of zygotes and embryos of the Fucales. Proc. Int. Seaweed Symp. 8: $117-124$

Norton, T. A. (1983). The resistance to dislodgement of Sargassum muticum germlings under defined hydrodynamic conditions. J. mar. biol. Ass. U. K. 63: 181-193

Oltmanns, F. (1889), Beiträge zur Kenntnis der Fucaceen. Bibl. bot. 14: 1-94

Ortega, S. (1981). Environmental stress, competition and dominance of Crasstostrea virginica near Beaufort, North Carolina, USA Mar. Biol. 62: 47-56

Palumbi, S. R. (1984). Measuring intertidal wave forces. J. exp. mar. Biol. Ecol. 81: 171-179

Patterson, B. P. (1986). Ecological relationships between germlings of Ascophyllum nodosum (L.) Le Jol. and the herbivorous snajl Littorina Littorea L. M. S. thesis, University of Maine, Orono

Printz, H. (1956). Recuperation and recolomization in Ascophyllum. Proc. Int. Seaweed Symp. 2: 194-197

Reed, D. C., Laur, D. R., Ebeling. A. W. (1988). Variotion in algal dispersal and recrutment: the importance of episodic events. Ecol. Monogr. 58: 321-335

SAS Institute Inc. (1982). SAS user's guide: statistics. SAS Institute Inc. Cary, NC

Schonbeck, M. W. Norton, T. A. (1980). Factors controlling the lower limits of fucoid algae on the shore. J. exp. mar. Biol. Ecol. 43: 131-150

Schwenke, H. (1971). Water ovement, 2. Plants. In: Kinne, O (ed.) Marine ecology. Vol.1, Part 2. Wiley, London, p. 1091-1121

Sebens, K. P. (1982). Asexual reproduction in Anthopleura elegantissima (Anthozoa: Actiniaria): seasonality and spatial extent of clones. Ecology 63: 434-444

Sebens, K. P., Lewis, J. R. (1985). Rare events and population structure of the barnacle Semibalanus cariosus (Pallas, 1788). J. exp. mar. Biol. Ecol. 87: 55-65

Sheader, A., Moss, B. (1975). Effects of light and temperature on germination and growth of Ascophyllum nodosum (L.) Le Jol. Estuar. coast mar. Sci. 3: 125-132

Sokal, R. R., Rohlf, F. J. (1981). Biometry, 2nd edn. W. H. Freeman and Co.. New York

Sousa, W. P. (1984). Intertidal mosaics: patch size, propagule

This article was presented by Professor M. Neushul, Santd Barbara, California, USA availability, and spatially variable patterns of succession. Ecology 65: 1918-1935

Sundene, 0. (1973). Growth and reproduction in Ascophyllum nodosum (Phaeophyceae). Norw. J. Bot. 20: 249-255

Tegner, M. J. (1986). Variations in surface currents and recruitment success. In: Thompson, M., Sarojini, R., Nagabhushanam, R. (eds.) Biology of benthic marine organisms: technicques and methods as applied to the Indian Ocean. A. A. Balkema, Rotterdam, p. 323-329

Topinka, J. A., Tucker, L., Korjeff, W. (1981). The distribution of fucoid macroalgal biomass along central coastal Maine. Botanica mar. 24: 311-319

Underwood, A. J. (1986). Physical factors and biological interactions: the necessity and nature of ecological experıments. In: Moore, P. G., Seed, R. (eds.) The ecology of rocky coasts. Columbia Univ. Press, New York, p. 372-390

Underwood, A. J., Denley. E. J. (1984). Paradigms, explanations, and generalizations in models for the structure of intertidal communities on rocky shores. In: Strong, D. R., Simberloff, D., Abele, L. G., Thistle, A. B. (eds.) Ecological communities: conceptual issues and the evidence. PrinceIon Unversity Press, Princeton, p. 151-180

Vadas, R. L. (1972). Marine algae. In. Third annual report, Maine Yankee Atomc Power company, Augusta, Maine, p. $250-310$

Vadas, R. L. (1979). Seaweeds: an overview; ecological and econornic importance. Experientia 35: 429-432

Vadas, R. L. Keser, M., Larson, B. (1978). Effects of reduced temperatures on previously stressed populations of an intertidôl alga. In: Thorpe, J. H., Gibbons, J, W. leds.) Energy and environmental stress in aquatic systems. DOE Symposium Series (Conf-771114, NTIS), Augusta, Georgia, p. 434-451

Vadas, R. L., Keser, M., Larson, B., Grant, W. S. (1977). Influence of Littorina littorea on algal zonation. Proc. Int. Seaweed Symp. 12: 84

Vadas, R. L., Keser, M., Rusanowski, P. C. (1976). Influence of thermal loading on the ecology of intertidal algae. In: Esch, G. W., McFarlane, R. W. (eds) Thermal ecology II. ERDA Symposium Series (Conf-750425, NTIS), Augusta, Georgia, p. 202-212

Vadas, R. L., Miller, S. L., Bolis, C. M., Bacon. L., Wright, W (1982). Population dynamics of Ascophylum rodasum: factors influencing recruitment and germlings. 1st Int. Phycol. Cong, Memorial University St. Johns, Newfoundland, Canada, p. $5:$

Vadas, R. L., Wright, W. A. (1986). Recruitment, growth and management of Ascophyllum nodosum. Actas II Congr. Algjas mar. chil. 2: 101-113

Vahl, O. (1982). Long-term variations in recruitment of the Iceland scallop Chlamys islandica from Northern Norway. Neth. J. Sea Res. 16: 80-87

Velmirov, B. (1983). Succession in a kelp bed ecosystem; clearing of primary substrate by wave-induced kelp sweeping. Oceanologica Acta No SP p. 201-206

Vogel, S. (1981), Life in moving fluids, the physical biology of flow. Princeton Univ. Press, Princeton

Watson, D. C., Norton. T. A. (1985). Dietary preferences of the conmon periwinkle, Littorina Litorea (L.) J. exp. mar. Bıol. Ecol. 88: 193-211

White, A. S. (1985). Presettlement regeneration patterns in a southwestern ponderosa pine stand. Ecology 66: 589-594

Mänuscript first received: September 26, 1988

Revised version accepted: December 12, 1989 